\title{
Aktuell forskning/litteratur
}

\section{Forebygging av selvmord i psykisk helsevern - ny kunnskapsoversikt}

Nasjonalt kunnskapssenter for helsetjenesten har nylig utgitt en ny kunnskapsoversikt om hvilken effekt psykoterapi, medikamentelle intervensjoner og elektrokonvulsiv terapi kan ha i forhold til å forebygge suicidal atferd hos pasienter som behandles i psykisk helsevern. Rapporten er utarbeidet etter oppdrag fra Sosial- og helsedirektoratet og er et grunnlag for utarbeidelse av nasjonale faglige retningslinjer for selvmordsforebyggende arbeid i den psykiatriske spesialisthelsetjenesten. Det vil komme en del to som også ser på andre tiltak.

Bak kunnskapsoversikten står en tverrfaglig sammensatt ekspertgruppe bestående av prof. Lars Mehlum (faglig leder) fra SSFF, Inst. for psykiatri, $\mathrm{UiO}$, seniorrådgiver Kurt Myhre (prosjektleder) fra Nasjonalt kunnskapssenter, forsker Fredrik Walby fra SSFF og Psyk. avd., Diakonhjemmets sykehus, prof. Øivind Ekeberg fra UiO/Ullevål universitetssykehus, forsker Gudrun Dieserud fra Nasjonalt folkehelseinstitutt og Bærum kommune, forskningssykepleier Liv Mellesdal fra Psyk. div., Helse Bergen, prof. Berit Grøholt fra Institutt for psykiatri, $\mathrm{UiO}$ og Senter for psykisk helse, barn og ungdom, Ullevål universitetssykehus.

Ekspertgruppen har gjennomgått relevant vitenskapelig litteratur funnet ved systema- tiske $s \varnothing \mathrm{k}$ i fem litteraturdatabaser per mai 2005, og det ble inkludert litteratur så langt tilbake som databasene gikk.

Kunnskapsoversikten konkluderer med at enkelte studier har rapportert at psykoterapi reduserte selvmordsatferd mer enn kontrollbehandling. Dette var studier av kognitiv atferdsterapi, dialektisk atferdsterapi gitt til pasienter med borderline personlighetsforstyrrelse og dagavdelingsbasert psykodynamisk orientert psykoterapi gitt til pasienter med borderline personlighetsforstyrrelse. Multisystemisk terapi gitt til ungdommer med behov for akuttinnleggelse i psykiatrisk avdeling ble også rapportert å redusere selvmordsatferd mer enn kontrollbehandling. Når det gjelder medikamentelle intervensjoner, viste flertallet av studier som inngår i kunnskapsoversikten at antidepressiver (hovedsakelig SSRI, TCA og MAOIpreparater) reduserte nivået på depresjon, selvmordstanker, og i noen få tilfeller selvmordsatferd mer enn placebo hos pasienter med markert depresjon, men med relativt lav grad av selvmordsrisiko. I om lag halvparten av disse studiene var selvmordstruede pasienter ekskludert. En har ikke funnet holdepunkter for at det skjer en forverring av selvmordsrisiko under behandling med antidepressiver sammenliknet med kontrollbetin- gelser. For barn og unge under 18 år har flere lands legemiddelmyndigheter nå vurdert at de fleste SSRI-preparater har en uheldig balanse mellom nytte- og skadevirkninger og frarår derfor bruk av disse preparatene i behandling av depresjon i denne aldersgruppen. Det ble funnet en signifikant effekt av litium i å redusere selvmord og selvmordsfors $\varnothing \mathrm{k}$ hos pasienter med stemningslidelser. Enkelte studier rapporterte at atypiske nevroleptika reduserer selvmordsatferd hos pasienter med schizofreni sammenliknet med andre antipsykotika. Det ble ikke funnet studier som kan belyse mulige effekter av elektrokonvulsiv terapi på selvmordsatferd.

Det er viktig å være oppmerksom på noen begrensninger ved den refererte forskningslitteraturen. For det første baserte flertallet av studiene seg på kortvarige intervensjoner og har metodiske svakheter. Flertallet av studiene ekskluderte pasienter med stor selvmordsfare, noe som kan giøre det vanskelig å overføre resultatene til vanlig klinisk praksis. Flertallet av studiene hadde også små utvalg og begrensede muligheter for å påvise effekter. Risikoen er derfor til stede for at reelle behandlingseffekter kan ha blitt oversett.

kunnskapssenteret.no/filer/rapport

24_06_selvmord_del_I.pdf

Lars Mehlum

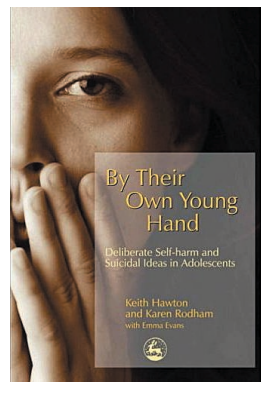

Ny bok

Keith Hawton and Karen Rodham, with Emma Evans

By their own young hand: Deliberate selfharm and suicidal ideas in adolescents

London; Philadelphia: Jessica Kingsley, 2006. ISBN 1-84310-230-7

At ungdom skader seg selv med vilje, vekker stor interesse og bekymring i ulike deler av barne- og ungdomsfeltet. Det finnes ulike beskrivelser av fenomenet, og ungdom som utfører slike handlinger omtales ofte som selvskadere. I Hawton og medarbeideres bok defineres villet egenskade som følger: enhver viljeshandling som ikke førte til døden, men der personen utførte handlinger som var egnet til å skade seg selv uavhengig av bakenforliggende intensjon.

Hawton er professor i psykiatri og leder av Senter for selvmordsforskning ved Universitetet i Oxford. Hawton regnes som en av de største suicidologer, og er meget aktiv innenfor flere felter. Rodham er psykolog og underviser ved Universitetet i Bath. Med seg har de to fått Emma Evans som også er psykolog. Begge de sistnevnte har vært forskningsmedarbeidere på Hawtons senter.

I hovedtrekk baserer bokens innhold seg på en nylig gjennomf $\varnothing$ rt unders $\varnothing$ kelse i England som vedrører villet egenskade i den generelle ungdomsgruppen. Unders $\varnothing$ kelsen tok utgangspunkt i svarene elever ved utvalgte skoler ga vedrørende villet egenskade og suicidaltanker. 6000 ungdom i alderen 15-16 år ble bedt om å svare på om de hadde erfaring med å skade seg selv med vilje, hva slags tanker de har hatt knyttet til dette, deres hjelp-søkeratferd, og om hvem ungdommen selv ser på som mulige hjelpere. Boken fors $\emptyset$ ker gjennom ulike kapitler i første del å besvare følgende spørsmål: Hvor mange, og hvem utfører gjentatt villet egenskade? Hva slags andre vansker har disse? Hvem snakker ungdom med om sine problemer? I andre del presenterer boken prak tiske konsekvenser for forebyggingsarbeid og for behandling av villet egenskade hos ungdom.

Unders $\varnothing$ kelsen ble gjort i samarbeid med internasjonale forskningsmiliøer i den såkalte CASE-studien (Child and Adolescent Self Harm in Europe), der også Norge deltar.

Resultatene sammenliknes landene imellom. Emma Evans har også sammenstilt resultatene i England med annen epidemiologisk forskning omkring utbredelse av villet egenskade, og boken viser til Evans systematiske oversikt.

Unders $\varnothing$ kelsen viser oppsiktsvekkende høye resultater vedrørende utbredelsen av villet egenskade med et gjennomsnitt på ca 6,9\% (3\% gutter mot $11 \%$ jenter). I denne skoleundersøkelsen til Hawton og kolleger var det en såkalt community-based rekruttering. En del av forklaringen på den høye utbredelsen en finner i denne studien i forhold til tidligere anslag, er at en vanligvis har gjort studier på ungdom som har vært på sykehus etter fors $\varnothing \mathrm{k}$ på egenskade. Dette viser at det er svært mange som ikke kommer i kontakt med sykehus eller hjelpeapparat etter villet egenskade.

Boken fremstår som en praktisk rettet hånd- bok som oppsummerer kunnskapen som finnes omkring ungdom og villet egenskade. Dette får Hawton og kolleger til, ved både å inkludere resultater fra den nye unders $\varnothing$ kelsen, å diskutere implikasjoner av dette, og ved å gi praktiske føringer. Forfatterne er tydeligvis meget erfarne i forskningssammenheng, og underst $\varnothing$ tter og diskuterer hele tiden sine resultater i lys av annen publisert litteratur. Kunnskapen er således meget interessant også utover Englands grenser. Boken er høyaktuell i Norge og bør sees i sammenheng med CASE studiens resultater. Mot slutten inkludereres instrumenter. Boken inneholder også nærmere 50 sider med vedlegg som er direkte praktisk rettede forslag til ungdom, hjelpere, og særlig lærere og hjelpere i skolesystemet. Hawton og kolleger mener skolen er en særdeles viktig arena for å fange opp og forebygge villet egenskade. Flertallet av de som oppgir å ha skadet seg selv, sier de primært snakker om dette med venner på skolen. Dette setter andre tenåringer i en vanskelig situasjon som det er viktig å få opplæring i forhold til, særlig opplæring i generell psykisk helse og omkring utviklingen av psykiske lidelser. Inklusjon av slike tema i skolen vil forebygge og hjelpe jevnaldrende til å snakke om problemene, samt sette dem bedre i stand til å henvende seg til voksne ved behov for hjelp. Boken anbefales som en meget god kunnskapsoppsummering og et praktisk oppslagsverk. Den er særlig egnet for hjelpere som jobber opp mot skolesystemet, og for dem som trenger praktisk rettet kunnskap om villet egenskade.

Anita J. Tørmoen, dr.gradsstipendiat ved SSFF 